\title{
REVIEWING THE PRODUCTION AND DEVELOPMENT OF 'PLACE' KNOWLEDGE IN A RECREATIONAL CONTEXT
}

\author{
Deniz Karagöz $z^{\mathrm{a}}$, Selin Kama ${ }^{\mathrm{b},}$ \\ ${ }^{\mathrm{a}}$ Department of Tourism Management, Anadolu University, Eskisehir, Turkey. \\ ORCID: 0000-0003-2868-8567 / e-mail:dkaragoz@anadolu.edu.tr \\ ${ }^{\mathrm{b}}$ Department of Tourism Management, Bitlis Eren University, Bitlis, Turkey. \\ ORCID: 0000-0002-2707-091X / e-mail:kamaselin@gmail.com
}

\section{KEYWORDS}

Recreation

Place

Space

Bibliometrics

Centrality

Network mapping

\begin{abstract}
This article aims to review the production, development and trends of place knowledge in the field of recreation from a bibliometric perspective. Data was obtained through a search of the terms 'recreation', 'place', and 'space' on the Web of Science database and by filtering research articles. Relational bibliometric techniques were used to analyze 148 articles. The development of spatial knowledge in the field of recreation was determined through centrality analysis and network mapping techniques. Besides, during the research, the most important articles, researchers, institutions and collaborations in the field were defined. According to the research findings, 302 researchers researched recreation and place, either in co-operation with each other or individually, in 43 journals. Place attachment, sense of place and place meaning have been determined as the dominant and main subject areas in the field of recreation.
\end{abstract}

\section{Introduction}

Due to the nature of recreation, whether it is physical or virtual, almost all leisure and recreational experiences occur and experience in space/ place context. The place has been conceptualized by creating comprehensive literature through studies in the disciplines of geography, landscape architecture, psychology, rural sociology, marketing, urban planning and literature. Place research has traditionally exhibited a positivist approach, with theories and methods based on scientific empiricism. Researchers have evaluated the objective properties of physical environments and tried to understand how the meanings of place can be associated with specific environments, and what kind of behavior can be practiced in these environments? These research traditions transferred to leisure, recreation and tourism contexts by examining the individual's sense of place within the context of emotional, cognitive and behavioral components. The approaches that followed the traditional approach give a dynamic view of the concept of place. These approaches focus on the transformation of place and its relationship with the individual. In parallel with these approaches, due to their importance in recreational experience, recreation and place studies have created a multi-disciplinary research area by using theoretical infrastructure and theories that have been acquired from different disciplines with a strong philosophical structure (Moncrief, 1970; Brown, Dyer, \& Whaley, 1973).

The main purpose of this study is to analyze the place knowledge produced and its evolution in the field of recreation. The study briefly shows the knowledge of place in the field of recreation and determines the social structure of this field. More specifically, within the study, the aim is to determine the approaches that play key roles in the field of recreation research, mainstream research topics, researchers and institutions, the knowledge base and development of the research field. Within this scope, research articles in the Web of Science Core Collection were examined through the quantitative approach of bibliometric analysis. In this context, degree centrality, the centrality of betweenness, Bonacich power, co-occurrence and co-citation analyses were performed. Within the current research, a macro view of the general development characteristics and trends of place, which are important contexts for recreational experience, recreation areas and planning are conceptualized. Therefore, a general view of the recreation/place research area is presented within this research.

In the following sections of the study, a literature review and method section on the concept of place in recreation are summarized. The findings section includes the results of the analysis with bibliometric techniques and network maps. In the discussion and

*Corresponding Author.

Received 10.02.2021; Received in revised form 10.03.2021; Accepted 13.03.2021 This article is licensed under a Creative Commons Attribution 4.0 International License. e-ISSN: 2687 - 3737 / ㄷ 2021 The Authors. Published by Anadolu University. http://dx.doi.org/10.48119/toleho.878332 
conclusion part, the information obtained from the study is discussed and recommendations for future research are included.

\section{Place in Recreation}

Almost all recreational activities take place within the scope of a place. In the context of environmental psychology, the place-individual relationship defines relationships that are built on the internal psychological and social processes of individuals and defines them based on various activities and events that are held in place (Smaldone et al., 2005). Positivist and postmodernist paradigms examine places where recreational activities are conducted, from different perspectives. The positivist research tradition defines place as a concrete physical environment in which people move. According to this view, places are objective, exist concretely, and are areas around which people direct their daily activities related to work, play, family and community. On the other hand, the postmodernist perspective questions the basis of the positivist point of view regarding concepts such as 'place', 'space', 'site' and 'location'. Postmodernists argue that traditional approaches cannot explain the identity of the place, the sense of place, the social structuring of places, and the symbolic value of places. Within this context, Soja (1989, p. 79) proposes an alternative, stating that the term 'place' is typically used in at least two different ways. First, it refers to physical environments as the context of social action (traditional conceptualization), and secondly, it treats place as a reference for socially structured contexts of interpersonal interaction and practice. To be more specific, while in the first proposition, place refers to a concrete site (the park, or a beach), in the second proposition place can be a non-physical place (such as a computer network of academicians) that is constantly reconstructed and reproduced. On the other hand, while place and space seem to be synonymous words that can be used interchangeably, the difference between the concepts clarifies the definition. Accordingly, while place defines a more personal environment that is experienced and interacted more often, space is a larger and less personal, more abstract and absolute concept (Okuyucu \& Günay Aktaş, 2017).

Parallel to the discussions of place and space, recreation researchers conducted phenomenological studies that shed light on how the place is experienced, its vital importance, subjective meaning and intuitive definitions of environmental experience (Fishwick \& Vining, 1992). In this context, in recreation studies, it has been associated with the fields of architecture and geography as a multidisciplinary research area in the context of recreational potential, location, recreational suitability, and spatial characteristics (Kienast, Degenhardt, Weilenmann, Wager, \& Buchecker, 2012). On the other hand, the concepts of space and place are used interchangeably in these studies and no difference is observed. For this reason, the concept of 'place' used in this study includes the subjective 'space' where the recreational experience takes place, and the 'place' can be reproduced and constructed with experiences.

In early research on the relationship between recreation and place, descriptive information was formed to create a social philosophy to identify problems, research priorities, basic variables and develop a methodology (Moncrief, 1970) by focusing on one-sided studies on the interaction of the environment and the individual (Fishwick \& Vining, 1992). By referring to a study by Tuan (1980), psychology and recreation researchers have formed a common consensus that certain 'places' and landscapes are important for individuals, especially in resource-based recreation (Tuan, 1980; Sime, 1995; Williams and Stewart, 1998; Stedman 2003a). According to Fishwick and Vining, (1992) this view argues that individuals reflect their identities to the place as a result of their repeated exposure to the places they visit and their social-psychological processes. In a sequel of this, reflection place takes on individual identities. Therefore, individuals' intrinsic motivations for visiting these places can be placed in many contexts like 'escape' (Tuan, 1998), 'connection' (Prayag \& Lee, 2019; Line \& Costen, 2011), and 'memory' (Lewicka, 2008; Kim \& Eves, 2012). In this context, places are constantly transformed, reconstructed and shaped depending on the nature of the recreational experiences performed, the individual and the environment. In this direction, it is similar to the proposition of Soja (1989) mentioned above.

Researchers examining the relationship between recreational behaviour and place in the leisure and recreation literature indicate that the place affects recreational preferences and behaviour (Robinson, 1972; McDonough, 1981; Hammitt, Kyle, \& Oh, 2009; Smith, Siderelis, \& Moore, 2010). Within this scope, the meanings of place (Lee, 1972; Kyle \& Chick, 2007), the use and selection of recreational areas (Moore \& Graefe, 1994; Kyle, et al, 2004), the transformation of places (Stokowski, 2002; Defilippis, 1997; Cheung and Tang, 2016), spatial preferences (Carls, 1974; Zhang et al, 2013; De Groot, van den Born, 2003; Abildtrup, et al. 2013), aesthetic value (Chenoweth \& Gobster, 1990), the scope of spatial experience (Zube, 1984; Weber \& Anderson, 2010), recreational potential (Weyland \& Laterra, 2014; Beeco, Hallo \& Brownlee, 2014), mapping (Murphy, 1963; Kienast, et al.2012; Beeco, Hallo \& Brownlee, 2014, Komossa, et al.2018 ) and carrying capacity (McCool, 1978; Beeco \& Brown, 2013; Beeco, Hallo, \& Brownlee, 2014) form the research area. In these studies, it is specified that recreationists assign emotional and symbolic meanings to the places where they perform their activities (Proshansky, Fabian, \& Kaminoff, 1983; Prayag \& Lee, 2018). Depending on its structural features, such as legibility, accessibility and atmosphere, these meanings become effective in identifying it just like an individual (Gieseking et al., 
2014). This identification and the assigned meaning, develop a sense of place and a sense of attachment to the place. In these studies, the concepts of place attachment, spatial bonding, spatial meaning and sense of place, which are interrelated and have many common aspects, come to the fore (Kyle \& Chick, 2007).

Place attachment, which is a complex and integrative phenomenon (Kaltenborn, 1997), presents a psychological structure that emerges with the emotional relationship between the individual and the place (Anderson \& Fulton, 2008; Hailu, et al., 2005; Kaltenborn, 1997) concerning the dimensions of place dependence and place identity (Schneider, 2009). On the other hand, spatial bonding refers to a certain identity and emotional bonding developed through the meaning attributed to the environment at the end of a long interaction process (Cheng \& Kuo, 2015). In this bond, both emotionality and cognition can be seen (Hammitt, Backlund, \& Bixler, 2006). Besides, place meaning is shaped by the experience of the visitors and the history of the place (Schneider, 2009). In other words, the place can be made meaningful by the transformation of 'place' into space (Kyle, Mowen, \& Tarrant, 2004), concerning the positive or negative role it plays in an individual's life (Manzo, 2005). Finally, the sense of place, which is superficial in the context of recreation, is defined by the perception of aesthetics and dwelling in social and geographical areas (Hay, 1998). These definitions cause place and recreation to be associated with environmental and outdoor education, sociology, social psychology, and environmental psychology (Hailu, Boxall, \& McFarlane, 2005; Beery \& Jönsson, 2017). Environmental psychology uses various models, such as Berlyne's (1973) aesthetic preferences model, the stimulus-organism-response model of Mehrabian and Russell (1973; 1980), and Kaplan and Kaplan's (1989) preference matrix, to examine the relationship between recreation and place from a cognitive, emotional, and behavioural perspective.

Researchers in the fields of recreation have examined the individual-place relationship from a cognitive perspective using various models developed in environmental psychology. Berlyne's (1973) aesthetic preferences model is the first model developed in this area. According to Berlyne (1973: 31), the source of all changes in behaviour is learning that develops dependent on interaction with the environment. Researchers argue that learned behaviour patterns can be observed when environmental conditions, certain physical performance and practices or environmental stimuli are perceived directly through the sensory organs. Raitz and Dakhil (1998), evaluate this view of Berlyne based on recreational preferences. They state that recreational preferences are learned in the physical environment from childhood and that the individual learns new and various recreational experiences as long as they live in a certain environment. Besides, researchers point out that when a person travels to a different location than their physical environment, the new environment will not only enable them to create a personal set of leisure preferences, but also a benchmarking environment in which they can compare all types of physical landscapes by their knowledge for recreational potential. However, according to Johnson (1998), the place is not only a learned area where ideas, emotions and memories are formed but also an emotional place where an individual or collective meanings are attributed to the experiences that are emerged in.

The Stimulus-Organism-Response (SOR) Model, developed by Mehrabian and Russell, explains that people's emotional states, such as happiness, excitement, arousal and approach-avoidance behaviour are affected by various elements in the places where they attribute meaning (Mehrabian and Russell, 1973; Russell and Mehrabian, 1978). Russell and Mehrabian (1976) define the concept of a stimulus with spatial characteristics, such as new, complex, intense, unfamiliar, impossible, unstable, dynamic or ambiguous. According to the researchers, stimuli includes many elements from information speed, simple sounds and shapes, complex tasks to interpersonal or social situations, depending on the type of activity individuals give to the places; the pleasure, arousal and so on. The pleasure, arousal and suchlike reactions occur depending on the type of activity individuals held in the places (Floyd, 1997) and reveal approach/avoidance behaviour, as it causes the individual to move away from the reallife area (Russell \& Mehrabian, 1978).

Another model developed by environmental psychology researchers is the Preference Matrix. Kaplan Kaplan, (1989) states that individuals displaying heterogeneous characteristics according to the preference matrix have an intersection point of general needs and, therefore, venues with an effective structure that best respond to needs are preferred. The benefits obtained vary, depending on the different characteristics exhibited by recreationists (Brouwer et al., 2010; Abildtrup et al., 2013). These benefits emerge when self-renewal motivated individuals, prefer comfortable and satisfying places that respond to their preferences and reduce their fears (Kaplan, Kaplan, \& Ryan, 1998). From a cognitive perspective, as a result of their nature, individuals prefer places with consistency, legibility that they can understand, and they see participatory environments as places with complexity, diversity, and mystery (Singh, Donavan, Mishra, \& Little, 2008).

\section{Method}

In this research, relational bibliometric techniques were used to determine the structures and connections of place knowledge in the area of recreation. Relational bibliometric techniques are generally used to analyze the intellectual and social structures in a particular field (Jiang, Ritchie, \& Benckendorff, 2019). The data was obtained 


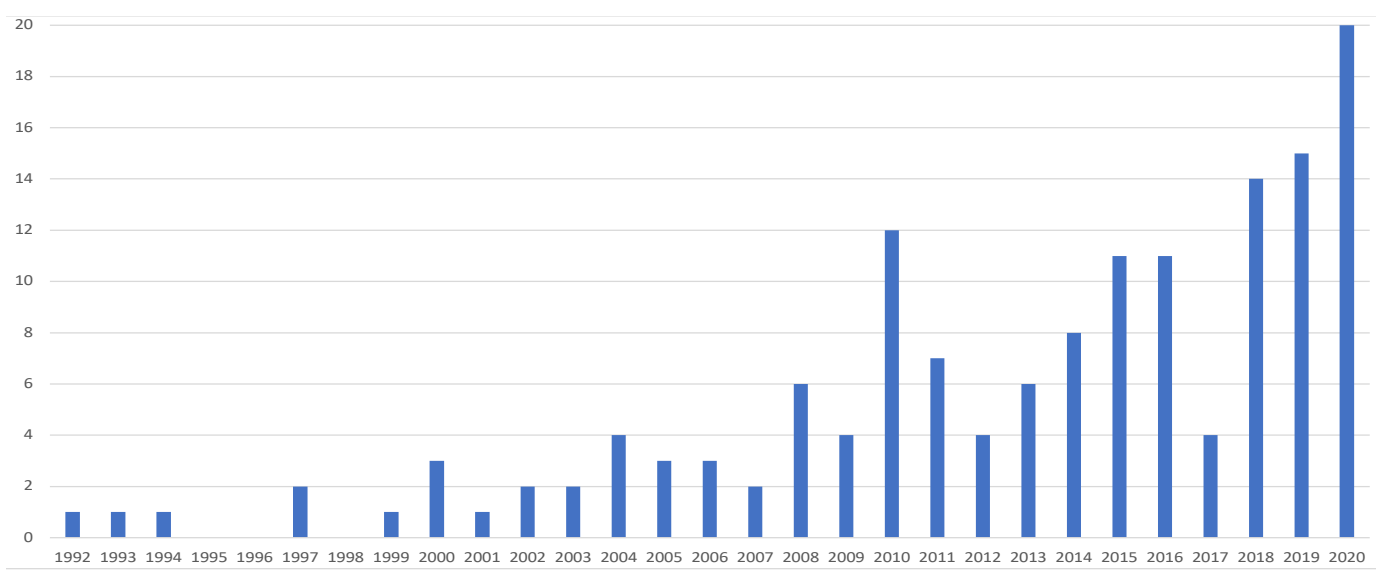

Figure 1. Publication Numbers of Articles by Years

from the Web of Science Core Collection database. The Web of Science Core Collection is shown to be the most effective database of scientific journals (Ramos-Rodriguez \& Ruiz-Navarro, 2004) in which articles accepted as 'certificated knowledge' are published (Mulet-Forteza et al., 2019). In the present study, three steps were followed to identify bibliometric studies published in scientific journals. In the first stage, the researchers scanned WoS with the keywords of 'recreation', 'place', and 'site'. The screening process was limited to articles in the 'hospitality, leisure, tourism, and sports categories and document types. In the first stage, a total of 159 articles were accessed. In the second stage, 159 articles were examined by two researchers to find articles directly related to recreation and place through keywords and abstracts. In this examination phase, to ensure the validity and reliability of the data, two researchers evaluated the articles once again by confirming the question, 'Is the article related to place in the area of recreation?'. As a result of these stages, 148 research articles were identified as having being published between 1992 and 2020 . The data collection process was carried out between 3-20 November 2020.

A spreadsheet including keywords, authors, publication year, published journal, themes researched, and authors' institutions, has been prepared for each article. Descriptive analysis and bibliometric analysis techniques were used to analyze the data. The state and development of place studies in recreation were examined by year of publication. The number of citations was analyzed to understand the impact of the articles, and to measure productivity. Besides, the representation of countries, institutions, journals or authors were determined by citation analysis. Centrality measurements were examined to identify critical researchers in the field. Finally, the co-occurrence of keywords, which is an important bibliometric technique to map the relationship between concepts, ideas and problems, and joint citation analysis (Small, 1973), which expands the citation analysis by adding insight to the intellectual structure of a field (Pasadeos et al., 1998), were applied. Excel was used for descriptive analysis, while Ucinet and VOSviewer software were used for bibliometric analysis and visualization of network maps.

\section{Findings}

\subsection{Distribution of Research Articles}

According to the analysis, research studies on the relationship between recreation and place started with the article, 'Beyond the Commodity Metaphor:

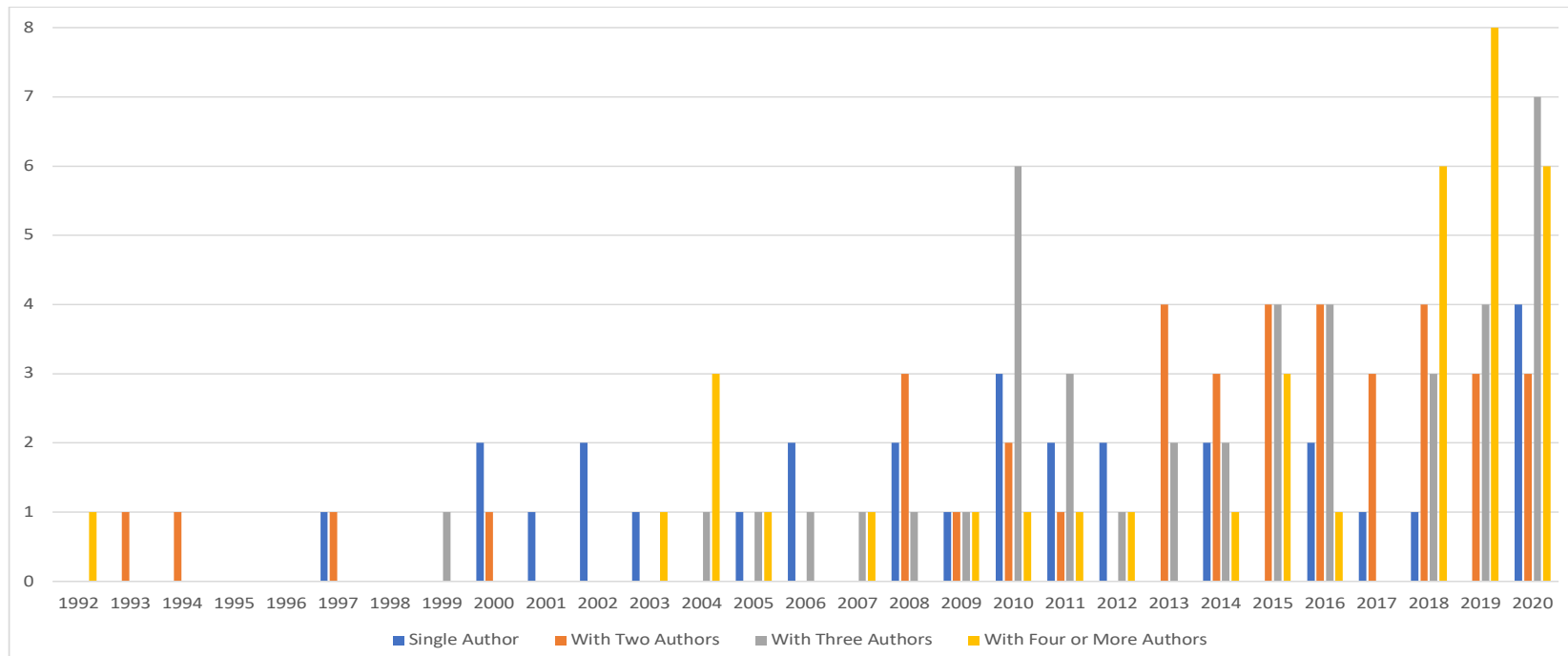

Figure 2. Author Distribution Chart by Years 
Table 1. Most Cited Top 20 Articles

\begin{tabular}{|c|c|c|c|c|c|c|}
\hline $\mathbf{N}$ & Article & Researchers & Year & Journal & $\begin{array}{l}\text { Total } \\
\text { Cit. } \\
\text { Score }\end{array}$ & $\begin{array}{l}\text { An- } \\
\text { nual } \\
\text { Cit. } \\
\text { Score }\end{array}$ \\
\hline 1 & $\begin{array}{l}\text { Beyond the Commodity Metaphor-Examining Emotional and } \\
\text { Symbolic Attachment to Place }\end{array}$ & $\begin{array}{l}\text { Williams, DR; Patterson, } \\
\text { ME; Roggenbuck,JW; } \\
\text { Watson, AE }\end{array}$ & 1992 & Leisure Sci. & 577 & 19.9 \\
\hline 2 & $\begin{array}{l}\text { Attachments to Recreation Settings: The Case of Rail-Trail } \\
\text { Users }\end{array}$ & Moore, Rl; Graefe, AR & 1994 & Leisure Sci. & 327 & 12.11 \\
\hline 3 & $\begin{array}{l}\text { Level of Specialization and Place Attachment: An Exploratory } \\
\text { Study of Whitewater Recreationists }\end{array}$ & Bricker, KS; Kerstetter, Dl & 2000 & Leisure Sci. & 297 & 14.14 \\
\hline 4 & $\begin{array}{l}\text { The Relationship Among Tourists' Involvement, Place Atta- } \\
\text { chment and Interpretation Satisfaction in Taiwan's National } \\
\text { Parks }\end{array}$ & $\begin{array}{l}\text { Hwang, SN; Lee, C; } \\
\text { Chen, HJ }\end{array}$ & 2005 & $\begin{array}{l}\text { Tourism } \\
\text { Man. }\end{array}$ & 226 & 14.13 \\
\hline 5 & $\begin{array}{l}\text { An Examination of the Relationship Between Leisure Activity } \\
\text { Involvement and Place Attachment Among Hikers Along the } \\
\text { Appalachian Trail }\end{array}$ & $\begin{array}{l}\text { Kyle, G; Graefe, A; Man- } \\
\text { ning, R; Bacon, J }\end{array}$ & 2003 & $\begin{array}{l}\text { J. of Leisure } \\
\text { Res. }\end{array}$ & 203 & 11.28 \\
\hline 6 & $\begin{array}{l}\text { Languages of Place and Discourses of Power: Constructing } \\
\text { New Senses of Place }\end{array}$ & Stokowski, PA & 2002 & $\begin{array}{l}\text { J. of Leisure } \\
\text { Res. }\end{array}$ & 197 & 10.37 \\
\hline 7 & $\begin{array}{l}\text { An Empirical Structural Model of Tourists and Places: Prog- } \\
\text { ressing Involvement and Place Attachment into Tourism }\end{array}$ & Gross, MJ; Brown, G & 2008 & $\begin{array}{l}\text { Tourism } \\
\text { Man. }\end{array}$ & 178 & 13.69 \\
\hline 8 & $\begin{array}{l}\text { The Role of the Rural Tourism Experience Economy in Place } \\
\text { Attachment and Behavioral Intentions }\end{array}$ & Correia Loureiro, SM & 2014 & $\begin{array}{l}\text { Int.J. of } \\
\text { Hosp. Man. }\end{array}$ & 177 & 25.29 \\
\hline 9 & $\begin{array}{l}\text { How Recreation Involvement, Place Attachment and Con- } \\
\text { servation Commitment Affect Environmentally Responsible } \\
\text { Behavior }\end{array}$ & Lee, $\mathrm{TH}$ & 2011 & $\begin{array}{l}\text { J. of Sus- } \\
\text { tainable } \\
\text { Tourism }\end{array}$ & 153 & 15.3 \\
\hline 10 & $\begin{array}{l}\text { Understanding Travel Constraints: Application and Extension } \\
\text { of a Leisure Constraints Model }\end{array}$ & $\begin{array}{l}\text { Nyaupane, GP; Andere- } \\
\text { ck, KL }\end{array}$ & 2008 & $\begin{array}{l}\text { J. of Travel } \\
\text { Res. }\end{array}$ & 139 & 10.69 \\
\hline 11 & $\begin{array}{l}\text { An Examination of Recreationists' Relationships with Activi- } \\
\text { ties and Settings }\end{array}$ & $\begin{array}{l}\text { Kyle, G; Bricker, K; Grae- } \\
\text { fe, A; Wickham, T }\end{array}$ & 2004 & Leisure Sci. & 121 & 7.12 \\
\hline 12 & $\begin{array}{l}\text { Effect of Activity Involvement and Place Attachment on Rec- } \\
\text { reationists' Perceptions of Setting Density }\end{array}$ & $\begin{array}{l}\text { Kyle, G; Graefe, A; Man- } \\
\text { ning, R; Bacon, J }\end{array}$ & 2004 & $\begin{array}{l}\text { J. of Leisure } \\
\text { Res. }\end{array}$ & 120 & 7.06 \\
\hline 13 & $\begin{array}{l}\text { Experience Use History, Place Bonding and Resource Substi- } \\
\text { tution of Trout Anglers during Recreation Engagements }\end{array}$ & $\begin{array}{l}\text { Hammitt, WE; Backlund, } \\
\text { EA; Bixler, RD }\end{array}$ & 2004 & $\begin{array}{l}\text { J. of Leisure } \\
\text { Res. }\end{array}$ & 119 & 7.00 \\
\hline 14 & $\begin{array}{l}\text { Racial and Gender Meanings of Why People Participate in } \\
\text { Recreational Fishing }\end{array}$ & Toth, JF; Brown, RB & 1997 & Leisure Sci. & 109 & 4.54 \\
\hline 15 & $\begin{array}{l}\text { Predictors of Behavioral Loyalty Among Hikers Along the } \\
\text { Appalachian Trail }\end{array}$ & $\begin{array}{l}\text { Kyle, G; Graefe, A; Man- } \\
\text { ning, R; Bacon, J }\end{array}$ & 2004 & Leisure Sci. & 100 & 5.88 \\
\hline 16 & $\begin{array}{l}\text { Nature of Place Attachment: A Study Among Recreation } \\
\text { Homeowners in Southern Norway }\end{array}$ & Kaltenborn, BP & 1997 & Leisure Sci. & 93 & 3.88 \\
\hline 17 & $\begin{array}{l}\text { Comparison of Place Bonding Models in Recreation Resource } \\
\text { Management }\end{array}$ & $\begin{array}{l}\text { Hammitt, WE; Kyle, GT;; } \\
\text { Oh, Chi-Ok }\end{array}$ & 2009 & $\begin{array}{l}\text { J. of Leisure } \\
\text { Res. }\end{array}$ & 76 & 6.33 \\
\hline 18 & $\begin{array}{l}\text { You Can Feel Them Looking at You: The Experiences of Ado- } \\
\text { lescent Girls at Swimming Pools }\end{array}$ & James, $\mathrm{K}$ & 2000 & $\begin{array}{l}\text { Journal of } \\
\text { Leisure Res. }\end{array}$ & 73 & 3.48 \\
\hline 19 & $\begin{array}{l}\text { Fairness of Prices, User Fee Policy and Willingness to Pay } \\
\text { Among Visitors to a National Forest }\end{array}$ & $\begin{array}{l}\text { Chung, JY. Kyle, GT, } \\
\text { Petrick, JF, Absher, JD }\end{array}$ & 2011 & $\begin{array}{l}\text { Tourism } \\
\text { Man. }\end{array}$ & 70 & 6.8 \\
\hline 20 & $\begin{array}{l}\text { Nature-Based Recreation and Spirituality: A Complex Relati- } \\
\text { onship }\end{array}$ & Heintzman, P. & 2009 & Leisure Sci. & 65 & 5.82 \\
\hline
\end{tabular}

Examining Emotional and Symbolic Attachment to Place' that was published in the Leisure Sciences Journal in 1992. A limited number of studies were conducted from 1992 to 2010. In 2010, twelve publications were printed, and it was determined that since 2010, interest in the field and research interest compared to the previous years have increased. The increase can be seen with fourteen articles published in 2018 compared to the highest number of articles published in 2020 with 20 articles.

When the distribution of researchers at the article level is examined by year, although the number of articles with a single author (30 articles) is high, it is noteworthy that collaboration was preferred by researchers and that the density of articles with three authors (43 articles) was remarkable. The first article, published in 1992, was published by four or more authors, and articles with a single author only began to be published in 1997. As mentioned earlier, in 2020, the highest number of publications was reached. The articles published with a single author were four, with two authors three, with three authors seven and with four or more authors six.

\subsection{The Most Influential Research in the Field}

The number of citations of a research article shows that the paper has a high scientific impact and contribution to the field (Aksnes, Langfeldt 
Table 2. Preferred Journals on Recreation and Place Research

\begin{tabular}{|c|c|c|c|c|c|c|c|}
\hline $\mathbf{N}$ & Journal & f & $\%$ & $\mathbf{N}$ & Journal & $\mathbf{f}$ & $\%$ \\
\hline 1 & Leisure Sciences & 28 & 18.92 & 22 & Recreational Sports Journal & 2 & 1.35 \\
\hline 2 & Journal of Leisure Research & 19 & 12.84 & 23 & Tourism & 1 & 0.68 \\
\hline 3 & Journal of Park and Recreation Administration & 15 & 10.14 & 24 & $\begin{array}{l}\text { Journal of Tourism Culture and Territorial } \\
\text { Development }\end{array}$ & 1 & 0.68 \\
\hline 4 & Journal of Outdoor Recreation and Tourism & 12 & 8.11 & 25 & International Journal of the History of Sport & 1 & 0.68 \\
\hline 5 & Journal of Sustainable Tourism & 7 & 4.73 & 26 & Current Issues in Tourism & 1 & 0.68 \\
\hline 6 & Tourism Geographies & 6 & 4.05 & 27 & Ecosphere & 1 & 0.68 \\
\hline 7 & Tourism Management & 5 & 3.38 & 28 & Journal of Heritage Tourism & 1 & 0.68 \\
\hline 8 & $\begin{array}{l}\text { Journal of Outdoor Recreation Education and } \\
\text { Leadership }\end{array}$ & 4 & 2.70 & 29 & $\begin{array}{l}\text { International Journal of Sport Policy and Pol- } \\
\text { itics }\end{array}$ & 1 & 0.68 \\
\hline 9 & Leisure Studies & 3 & 2.03 & 30 & Journal of Sport and Social Issues & 1 & 0.68 \\
\hline 10 & Annals of Leisure Research & 3 & 2.03 & 31 & Environmental Management & 1 & 0.68 \\
\hline 11 & Loisir \& Societe-Society and Leisure & 3 & 2.03 & 32 & Tourist Studies & 1 & 0.68 \\
\hline 12 & $\begin{array}{l}\text { Pedagogics Psychology Medical-Biological } \\
\text { Problems of Physical Training and Sports }\end{array}$ & 3 & 2.03 & 33 & $\begin{array}{l}\text { Journal of Destination Marketing and Man- } \\
\text { agement }\end{array}$ & 1 & 0.68 \\
\hline 13 & $\begin{array}{l}\text { European Journal of Tourism Hospitality and } \\
\text { Recreation }\end{array}$ & 2 & 1.35 & 34 & Worldwide Hospitality and Tourism Themes & 1 & 0.68 \\
\hline 14 & $\begin{array}{l}\text { International Journal of Culture Tourism and } \\
\text { Hospitality Research }\end{array}$ & 2 & 1.35 & 35 & Anais Brasileiros De Estudos Turisticos-Abet & 1 & 0.68 \\
\hline 15 & Visitor Studies & 2 & 1.35 & 36 & Journal of Travel Research & 1 & 0.68 \\
\hline 16 & World Leisure Journal & 2 & 1.35 & 37 & Tourism Analysis & 1 & 0.68 \\
\hline 17 & Urban Forestry \& Urban Greening & 2 & 1.35 & 38 & Sustainability Science & 1 & 0.68 \\
\hline 18 & Journal of Place Management and Development & 2 & 1.35 & 39 & Journal of Travel \& Tourism Marketing & 1 & 0.68 \\
\hline 19 & $\begin{array}{l}\text { Pasos-Revista De Turismo Y Patrimonio Cul- } \\
\text { tural }\end{array}$ & 2 & 1.35 & 40 & $\begin{array}{l}\text { International Journal of Hospitality Manage- } \\
\text { ment }\end{array}$ & 1 & 0.68 \\
\hline 20 & Research Quarterly for Exercise and Sport & 2 & 1.35 & 41 & Journal of Tourism and Cultural Change & 1 & 0.68 \\
\hline \multirow[t]{3}{*}{21} & Tourism and Hospitality Research & 1 & 0.68 & 42 & Social \& Cultural Geography & 1 & 0.68 \\
\hline & & & & 43 & $\begin{array}{l}\text { Journal of Policy Research in Tourism Leisure } \\
\text { and Events }\end{array}$ & 1 & 0.68 \\
\hline & Total Published Article & 148 & & & Total Percentage & $100 \%$ & \\
\hline
\end{tabular}

\& Wouters, 2019). Therefore, in this study, the most effective studies in the field were determined according to the number of citations they received. The most effective research studies related to place in recreation are given in Table 1. Table 1 contains information regarding the top twenty articles with the most citations, the author(s) of the article, the publication year of the article, the journal in which it was published, the total number of citations made and the annual citation rate. According to the findings of the research, the article named 'Beyond the Commodity Metaphor: Examining Emotional and Symbolic Attachment to Place', in which Williams et al. (1992) examine emotional and symbolic attachment, ranks first with 577 total citations and a 19.9 annual citation rate. The study 'Attachments to Recreation Settings: The Case of Rail-Trail Users' by Moore and Graefe (1994), which examines adherence to recreation areas, ranks second with 327 total citations and a 12.11 annual citation rate; The study 'Level of Specialization and Place Attachment: An Exploratory Study of Whitewater Recreationists', in which Bricker and Kerstetter (2000) examine the specialization levels of recreationists and their attachment to place, is in third place with a total number of 297 citations and a 14.14 annual citation rate.

\subsection{Distribution of Journals}

It is determined that 148 articles examined within the scope of this study were published in 43 different journals. As can be seen in Table 2, the journal most preferred by researchers is 'Leisure Science' with 28 articles. 'Leisure Science' is followed by the 'Journal of Leisure Research' with 19 articles and the 'Journal of Park and Recreation Administration with 15 articles. In the scope of this study it is noted that, following the 'Journal of Outdoor Recreation 
Table 3. Degree Centrality, Normalized Bonacich Power, and Betweenness Centrality of Authors

\begin{tabular}{cllllll}
\hline N & Degree Centrality & \multicolumn{3}{c}{ Normalized Bonacich Power } & \multicolumn{2}{c}{ Betweenness Centrality } \\
\hline 1 & Kyle G & 26 & Davenport MA & 7.857 & Kyle G & 2.662 \\
2 & Graefe A & 18 & Smith JW & 7.790 & Graefe AR. & 1.889 \\
3 & Davenport MA & 17 & Seekamp E & 7.669 & Wynveen CJ & 1.584 \\
4 & Smith JW & 16 & Mccreary A & 7.669 & Moore RL. & 1.518 \\
5 & Seekamp E & 14 & Hestetune, A & 3.359 & Smith JW & 1.376 \\
6 & Mccreary A & 14 & Holmberg, K & 3.359 & Stanis Saw & 1.305 \\
7 & Glover TD & 10 & Wilson, B & 3.359 & Schneider IE & 1.294 \\
8 & Manning R & 9 & Kanazava, M & 3.029 & Davenport MA & 0.619 \\
9 & Bacon J & 9 & Fatoric, S & 3.029 & Shinew K & 0.384 \\
10 & Stanis Saw & 9 & Kyle G & 1.452 & Oh Chi-OK & 0.378 \\
11 & Oh Chi-ok & 8 & Graefe A & 1.333 & Hamitt, WE & 0.312 \\
12 & Absger JD & 8 & Manning R & 1.040 & Leahy JE & 0.260 \\
13 & Holland SM & 7 & Bacon J & 1.040 & Sutton SG & 0.146 \\
14 & Brownlee MTJ & 7 & Roger L Moore & 0.885 & Kelly S. Bricker & 0.132 \\
15 & Campbell LK & 7 & Leahy JE & 0.877 & Glover TD & 0.117 \\
16 & Rose J & 7 & Anderson DH & 0.858 & Pitas, NA & 0.065 \\
\hline
\end{tabular}

and Tourism', where 12 publications on the subject are printed, the number of publications is limited (under seven) in 16 journals. Additionally, only one article is published in 24 journals. Therefore, the first four journals related to place in the recreational area constitute $50.01 \%$ of the total publications.

\subsection{Critical Researchers in the Field}

The analysis made within the scope of this study shows that 148 articles were prepared by 302 authors. The first 16 critical researchers in the network were determined based on the degree and betweenness centrality, Bonacich's power analysis. The analysis was performed using Ucinet software. In Table 3, it can be seen that Gerard Kyle and Alan R. Graefe are the most critical authors in the network for degree centrality and betweenness centrality measurements. According to this result, Gerard Kyle and Alan R. Graefe have developed a strong collaboration with the authors on the network and act as a high degree bridge within the network. In terms of Bonacich's power scores, M. A. Davenport and J.W. Smith have the highest scores. The Bonacich power takes the quality of the connection into account rather than the number of connections. Therefore, it gives different results from the degree centrality and betweenness measurements (Hansen et al, 2011). In this context, the high Bonachich power of Davenport and Smith shows that the authors with whom the researchers collaborate are critical in the network.

\subsection{Keywords analysis: Co-occurrence}

Keyword co-occurrence analysis was conducted to determine the themes used in the research field

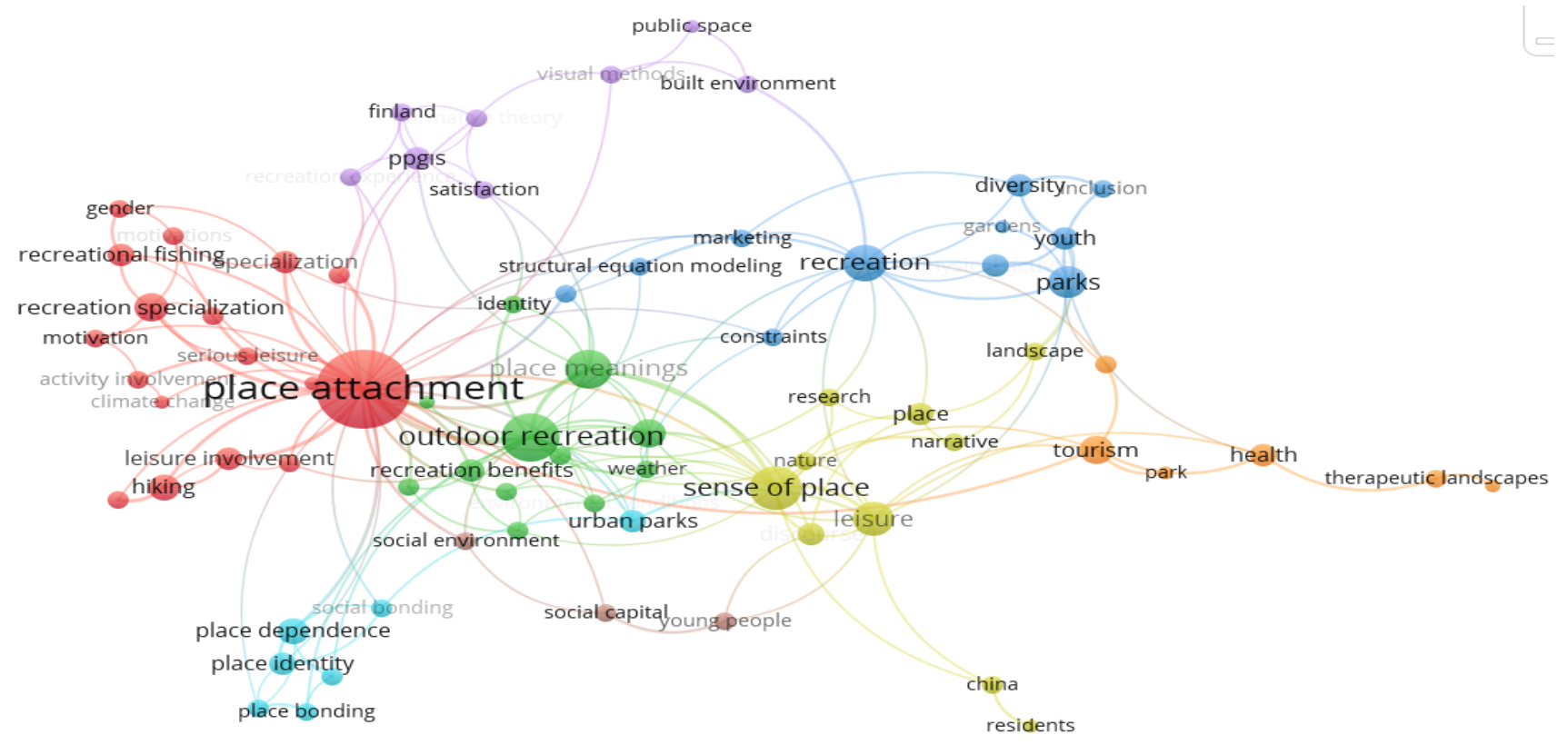

Figure 3. Keyword Co-View Network 
Table 4. Keyword Views Together and Total Link Strength

\begin{tabular}{lcc}
\hline Key Word & Co-View/Occurrences & Total link strength \\
\hline Place attachment & 47 & 38.00 \\
Outdoor recreation & 15 & 14.00 \\
Sense of place & 11 & 11.00 \\
Place meanings & 10 & 9.00 \\
Recreation & 10 & 8.00 \\
Leisure & 7 & 7.00 \\
Parks & 6 & 6.00 \\
Nature-based tourism & 7 & 5.00 \\
Recreational specialization & 5 & 5.00 \\
Tourism & 5 & 5.00 \\
Place dependence & 5 & 4.00 \\
\hline
\end{tabular}

and the relationships between these themes. For this purpose, studies in which two keywords appear together (keywords highlighted by the authors in each article) were included in the analysis. As a result of the analysis, it was determined that 74 out of 513 keywords in the articles formed eight clusters, depending on the threshold of appearing together twice.

Figure 3 illustrates the main keywords and the size of nodes (depending on the threshold of appearing twice). The nodes are shown as circles in the network, while colours in the network indicate the resulting clusters. Similar colours of nodes and keywords mean they belong to the same cluster (a group of related keywords), and each node belongs to only one cluster. In the network, shorter distances between nodes show the stronger relationship they have. When we consider the biggest clusters, the largest cluster with 17 keywords is Cluster 1 (red nodes). Cluster 1 includes the theme of attachment to the place with the most connections in the network, and this theme is the most critical in the network. Besides, Cluster 1 contains the keywords of leisure, specialization, motivation, activity involvement, serious leisure time, gender, climate change, and environmental responsibility. It can be said that Cluster 2, the second main cluster in the network where the keywords are co-occurrence, is related to environmental issues. This includes biodiversity, environmental conditions, environmental protection behaviour, weather, national parks, outdoor recreation, nature-based tourism, recreation benefits keywords. Cluster 3 (blue nodes) with 11 keywords consists of recreation, parks, gardens, state parks, physical activity, marketing, limitations, diversity, youth and structural equation modelling keywords that are linked to each other.

The keyword with the highest total number of connections, and the highest number of views on the network, is place attachment with 47 views and

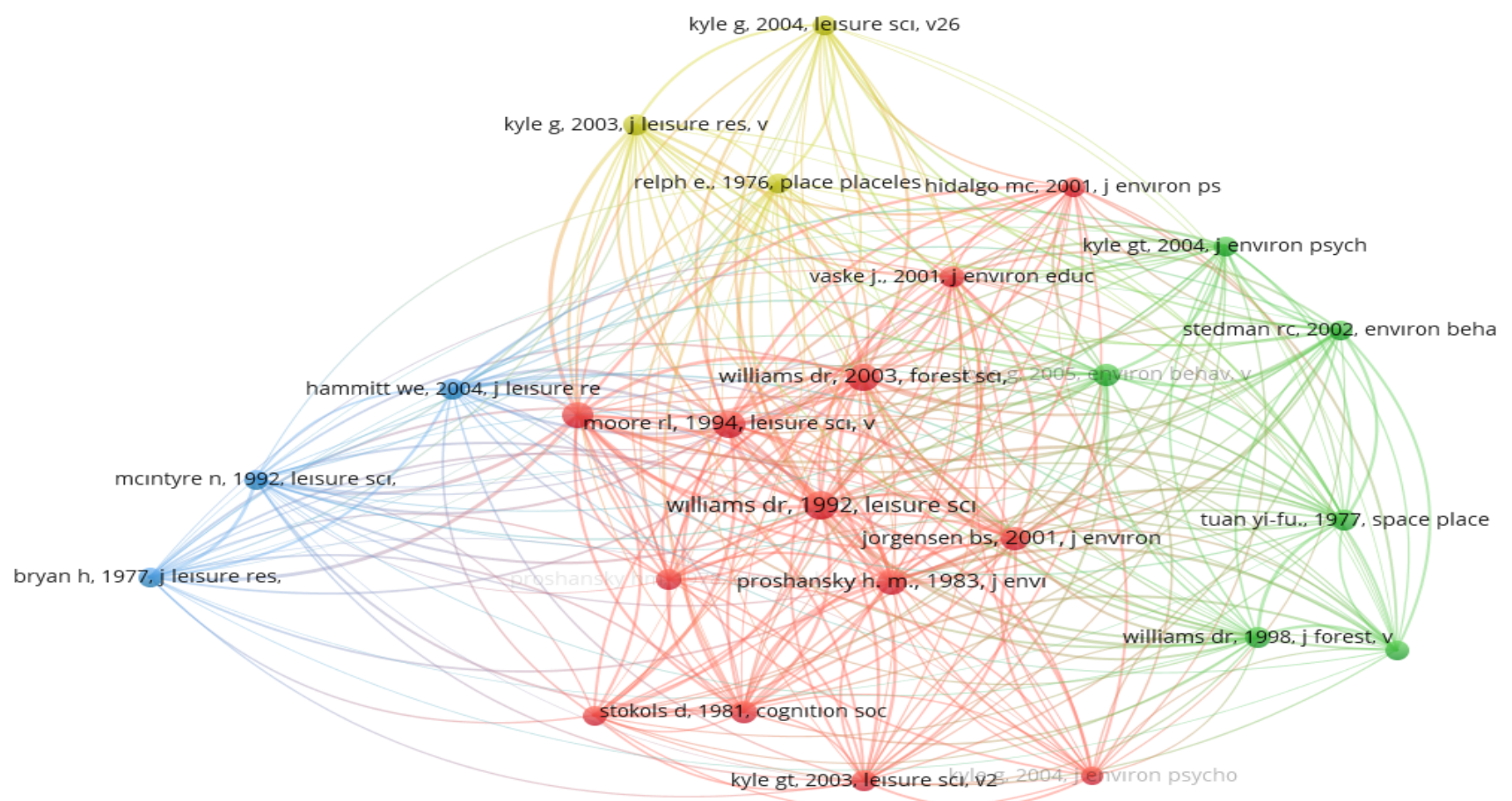

Figure 4. Reference Co-Citation Network 
Table 5. Reference Co-Citation Analysis Findings

\begin{tabular}{|c|c|c|c|c|c|c|}
\hline $\mathbf{N}$ & Researcher & Article & Journal & Year & Ref & $\begin{array}{l}\text { Total link } \\
\text { strength }\end{array}$ \\
\hline 1 & $\begin{array}{l}\text { Williams, DR; Patterson, } \\
\text { ME; Roggenbuck, JW Wat- } \\
\text { son, AE }\end{array}$ & $\begin{array}{l}\text { Beyond the Commodity Metaphor - Examining } \\
\text { Emotional and Symbolic Attachment to Place }\end{array}$ & Leisure Sciences & 1992 & 42 & 40 \\
\hline 2 & Moore, Rl; Graefe, AR & $\begin{array}{l}\text { Attachments to Recreation Settings - The Case of } \\
\text { Rail-Trail Users }\end{array}$ & Leisure Sciences & 1994 & 38 & 38 \\
\hline 3 & Williams DR; Vaske, JJ & $\begin{array}{l}\text { The Measurement of Place Attachment: Validity } \\
\text { and Generalizability of a Psychometric Approach. }\end{array}$ & Forest Science & 2003 & 35 & 35 \\
\hline 4 & Bricker, KS; Kerstetter, DL & $\begin{array}{l}\text { Level of Specialization and Place Attachment: An } \\
\text { Exploratory Study of Whitewater Recreationists }\end{array}$ & Leisure Sciences & 2000 & 34 & 34 \\
\hline 5 & $\begin{array}{l}\text { Proshansky, HM; Fabian, } \\
\text { AK; Kaminoff, R }\end{array}$ & $\begin{array}{l}\text { Place identity: Physical World Socialisation of the } \\
\text { Self. }\end{array}$ & $\begin{array}{l}\text { Journal of Environ- } \\
\text { mental Psychology }\end{array}$ & 1983 & 30 & 30 \\
\hline 6 & Jorgensen, BS; Stedman, RC & $\begin{array}{l}\text { Sense of Place as an Attitude: Lakeshore Owners' } \\
\text { Attitudes Toward Their Properties. }\end{array}$ & $\begin{array}{l}\text { Journal of Environ- } \\
\text { mental Psychology }\end{array}$ & 2001 & 27 & 27 \\
\hline 7 & $\begin{array}{l}\text { Kyle, G; Graefe, A.; Man- } \\
\text { ning, R. }\end{array}$ & $\begin{array}{l}\text { Testing the Dimensionality of Place Attachment in } \\
\text { Recreational Settings. }\end{array}$ & $\begin{array}{l}\text { Environment and Be- } \\
\text { havior }\end{array}$ & 2005 & 23 & 23 \\
\hline 8 & Vaske, J; Kobrin, KC & $\begin{array}{l}\text { Place Attachment and Environmentally Responsi- } \\
\text { ble Behavior. }\end{array}$ & $\begin{array}{l}\text { The Journal of Envi- } \\
\text { ronmental Education }\end{array}$ & 2001 & 20 & 20 \\
\hline 9 & $\begin{array}{l}\text { Kyle, G; Graefe, A.; Man- } \\
\text { ning, R., Bacon, J. }\end{array}$ & $\begin{array}{l}\text { An Examination of the Relationship between Lei- } \\
\text { sure Activity Involvement and Place Attachment } \\
\text { among Hikers along the Appalachian Trail. }\end{array}$ & $\begin{array}{l}\text { Journal of Leisure } \\
\text { Research }\end{array}$ & 2003 & 19 & 19 \\
\hline 10 & Proshansky, HM. & The City and Self-Identity. & Environ. and Behavior & 1978 & 19 & 19 \\
\hline 11 & Williams, DR; Stewart, SI & $\begin{array}{l}\text { Sense of Place: An Elusive Concept that is Finding } \\
\text { a Home in Ecosystem Management. }\end{array}$ & Journal of Forestry. & 1998 & 19 & 19 \\
\hline 12 & $\begin{array}{l}\text { Hammitt, WE; Backlund, } \\
\text { EA; Bixler, RD }\end{array}$ & $\begin{array}{l}\text { Experience Use History, Place Bonding and Re- } \\
\text { source Substitution of Trout Anglers During Rec- } \\
\text { reation Engagements. }\end{array}$ & $\begin{array}{l}\text { Journal of Leisure } \\
\text { Research }\end{array}$ & 2004 & 19 & 19 \\
\hline 13 & $\begin{array}{l}\text { Kyle, GT; Mowen, AJ; Tar- } \\
\text { rant, M }\end{array}$ & $\begin{array}{l}\text { Linking Place Preferences with Place Meaning: An } \\
\text { Examination of the Relationship Between Place } \\
\text { Motivation and Place Attachment. }\end{array}$ & $\begin{array}{l}\text { Journal of Environ- } \\
\text { mental Psychology }\end{array}$ & 2004 & 18 & 18 \\
\hline 14 & $\begin{array}{l}\text { Kyle, GT; Absher, JD; Grae- } \\
\text { fe, AR }\end{array}$ & $\begin{array}{l}\text { The Moderating Role of Place Attachment on the } \\
\text { Relationship Between Attitudes Toward Fees and } \\
\text { Spending Preferences. }\end{array}$ & Leisure Sciences & 2003 & 19 & 18 \\
\hline 15 & Stedman, RC & $\begin{array}{l}\text { Toward a Social Psychology of Place: Predicting } \\
\text { Behavior from Place-Based Cognitions, Attitude, } \\
\text { and Identity. }\end{array}$ & $\begin{array}{l}\text { Environment and Be- } \\
\text { havior }\end{array}$ & 2002 & 18 & 18 \\
\hline 16 & Hidalgo, MC; Hernandez, B & $\begin{array}{l}\text { Place Attachment: Conceptual and Empirical } \\
\text { Questions. }\end{array}$ & $\begin{array}{l}\text { Journal of Environ- } \\
\text { mental Psychology }\end{array}$ & 2001 & 18 & 18 \\
\hline 17 & Warzecha, CA; Lime, DW & $\begin{array}{l}\text { Place Attachment in Canyonlands National Park: } \\
\text { Visitors' Assessment of Setting Attributes on the } \\
\text { Colorado and Green Rivers. }\end{array}$ & $\begin{array}{l}\text { Journal of Park \& Rec- } \\
\text { reation Administration }\end{array}$ & 2001 & 17 & 17 \\
\hline 18 & Mcintyre, N; Pigram, JJ & $\begin{array}{l}\text { Recreation Specialization Re-examined: The Case } \\
\text { of Vehicle-Based Campers. }\end{array}$ & Leisure Sciences & 1992 & 16 & 16 \\
\hline 19 & Stedman, RC & $\begin{array}{l}\text { Is it Just a Social Construction? The Contribution } \\
\text { of the Physical Environment to Sense of Place. }\end{array}$ & $\begin{array}{l}\text { Society \&Natural Re- } \\
\text { sources }\end{array}$ & 2003 & 18 & 15 \\
\hline 20 & Bryan, $\mathrm{H}$. & $\begin{array}{l}\text { Leisure Value Systems and Recreational Special- } \\
\text { ization: The Case of Trout Fishermen }\end{array}$ & $\begin{array}{l}\text { Journal of Leisure } \\
\text { Research }\end{array}$ & 1977 & 16 & 15 \\
\hline
\end{tabular}

a 38.00 total link strength. Outdoor recreation (15 views; 14 total link strength), sense of place (11 views; 11 total link strength) and place meaning (10 views; 9 total link strength) are the other important keywords.

\subsection{Co-Citation}

Co-citation analysis was conducted to analyze the network relationships between influential articles in the field of recreation. Through this analysis, it is possible to examine the contribution of different disciplines in an interdisciplinary field, such as recreation. Co-citation analysis is taken into account when two items (author, journal or article) are cited simultaneously in a third study because they appear together in the new reference lists (Garrigos-Simon et al., 2019). Figure 4 shows a reference common network consisting of five references (nodes) and four clusters (the threshold value in the study was taken as 15). Nodes in the network represent cited references, and the size of a node is proportional to the number of citations received by cited references.

As can be seen in Table 5, Williams, D. R., Patterson, M.E, Roggenbuck, JW and Watson, A.E.(1992)‘Beyond the Commodity Metaphor: Examining Emotional and Symbolic Attachment to Place' article has the highest 


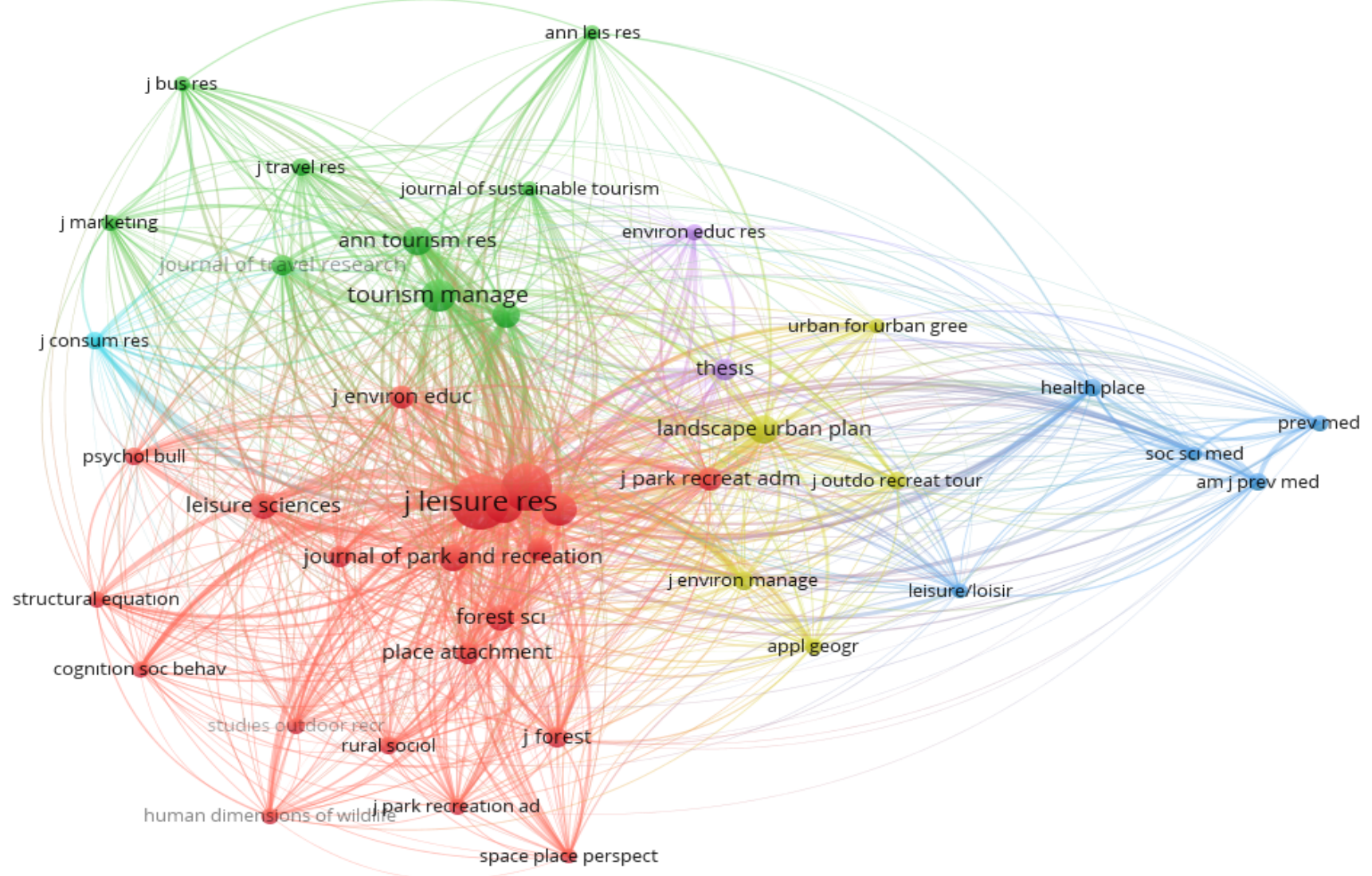

Figure 5. Common Citation Network

number of citations (42) and a total link strength of 40.00 and ranks first in the reference co-citation network. Moore, R. L. and Graefe, A. R. (1994), on the other hand, is in second place with 38 citations and a 38 total link strength in 'Attachments to Recreation Settings: The Case of Rail-Trail Users'. On the other hand, Williams, D. R.'s (2003) 'The measurement of Place Attachment: Validity and Generalizability of a Psychometric Approach' article ranks third in terms of citation and total link strength.

Secondly, a co-citation analysis of journals was conducted. Journal co-citation occurs when two journals receive a citation in a third source. Nodes in the network represent the most cited journals and their networked journals. Figure 5 shows the co-citation network of journals with 20 citation thresholds and the most representative 75 co-citation links. Three main clusters have been identified in the network that meets these criteria. As can be seen in Table 6, 'Journal of Leisure Research, and 'Leisure Science and Tourism Management are the most cited journals.

\section{Conclusion}

In this article, the production, development and trends of place knowledge in the field of recreation are examined from a bibliometric perspective. In this context, 148 articles have been gathered from the Web of Science database using the terms 'recreation', 'place', 'space' and by filtering the research articles. The relational bibliometric techniques used in this study enabled the determination of the structures

Table 6. Journals' Co-Citation Findings

\begin{tabular}{lll}
\hline Journal & Reference & $\begin{array}{l}\text { Total link } \\
\text { strength }\end{array}$ \\
\hline Journal of Leisure Research & 473 & 359.66 \\
Leisure Science & 433 & 356.87 \\
Tourism Management & 123 & 105.53 \\
Landscape and Urban Planning & 92 & 83.43 \\
Journal of Park and Recreation Administration & 84 & 78.45 \\
Annals of Tourism Research & 87 & 74.13 \\
Journal of Sustainable Tourism & 74 & 68.40 \\
Journal of Park and Recreation Administration & 54 & 50.78 \\
Journal of Environmental Education & 51 & 45.75 \\
Leisure Studies & 44 & 41.01 \\
\hline
\end{tabular}


and connections for place knowledge. To be more specific, the results obtained from the study determined the development of the knowledge produced in the field and the social structure in this field. Therefore, this enriches knowledge on the subject and contributes to academicians.

As a result of the analysis made within the scope of the study, it can be seen that studies examining the relationship between recreation and place started with one article, which was published in 1992. According to the findings, while attention in the field was very limited in the 1990s, it was observed that this attention started to increase after 2010. The interest of academics in recreation and place was probably increased due to the knowledge of individuals' behavioural patterns in service businesses, determined by various characteristics of place (Bitner, 1992; Wakefield \& Blodgett, 1996; Donovan \& Rossiter, 1982; Turley \& Milliman, 2000). In other words, in the field of recreation, the view that place is the determinant of the individual's behaviour (Stedman, 2002) started to be examined in 1992 and, after 2010, it became widespread and accepted knowledge.

From the results obtained from the research, it can be seen that the relationship between place and the individual in the context of recreation is associated with various themes, such as attachment to place, sense of place and place meaning. These themes may be expressed as the dominant and main topics of research in the field of recreation. Environmental psychology researchers state that the relationship between individual and place stems from an emotional memory that causes people to attach to place and to attribute meaning to it (Hammitt, Backland, \& Bixler, 2006). Therefore, psychological processes, such as attachment, meaning, and sense of place are seen as important sources of motivation for individuals to choose a particular place in recreation research (Young, 2007; Prayag \& Lee, 2018). In this context, recreation researchers tend to understand this complex relationship between the individual and place and to increase their knowledge of the subject. Besides, the prominence of certain themes, such as place attachment, identity, and meaningfulness shows that researchers in the field of recreation move away from the traditional approach and adopt the idea that the place is a more dynamic and social structure, and it follows the postmodern perspective.

The current research findings reveal that 302 researchers, who researched recreation and place, prepared 148 articles for publication, either in cooperation with each other or individually. Besides, it was noted that researchers collaborate with researchers working in different disciplines to reach a miscellaneous approach. This increasing structure of collaboration may reflect an increase that accompanies the trend to produce more quantitative and empirical studies in this field. These research studies reveal the multidisciplinary structure in the field of recreation (Merigó, Mulet-Forteza, Valencia, \& Lew, 2019). However, it can be seen that studies based on both geographical and architectural fields are insufficient (Wolfe, 1964; Hall \& Page, 2014).

According to the findings of the keyword cooccurrence analysis, the researches focused on certain themes, such as place attachment, leisure time involvement, specialization, motivation, serious leisure time, gender, climate change, environmental responsibility, biodiversity, environmental conditions, environmental protection behaviour, outdoor recreation, and nature-based tourism. Place attachment and involvement themes have been studied in the field of environmental psychology and psychology for many years. However, issues such as climate, climate change, biodiversity and environmental protection are relatively new, therefore, it seems that there is a gap in the field. On the other hand, social capital, social environment, youth, health and therapeutic recreation themes have been identified as subjects that are open to examination by researchers. Mapping bibliographic data can provide useful information on the current state of place information research concerning themes that have not received enough research attention to date. The data obtained in this research has the potential to assist in identifying and addressing key gaps in place research in recreation.

The bibliometric analysis findings of this research emphasize past and current research activities on place research in the field of recreation. These findings may guide researchers in newly developing fields. Furthermore, they can provide answers to important questions that researchers should consider when focusing on a research study regarding the recreationist-place relationship and interaction in the recreation field. In particular, the research results can help pinpoint gaps in the field and better explore factors that specifically influence publication trends. Besides, based on the fact that recreationists establish an emotional connection with the places where they realize their experiences, recreation managers and local/national administrations should pay attention to the planning and promotion of the places.

Asinotherstudies, thisresearchalsohaslimitations. First of all, the research data was obtained from a single database. Other databases may be included for a more detailed and comprehensive study in future research. Second, the data collection stage was limited to the category of 'accommodation, leisure time, tourism, and sports. When these limitations are removed in future studies, and other categories are included in the research, the multidisciplinary approach tendency in the field can be analyzed. Third, future studies may analyze books, conference papers, and other publications other than research articles. Besides, researchers could apply advanced bibliometric analysis, including research methods, author keyword cluster analysis, and citation score analysis, to better understand the evolution of place research in recreation. 


\section{References}

Abildtrup, J., Garcia, S., Olsen, S. B., \& Stenger, A. (2013). Spatial preference heterogeneity in forest recreation. Ecological Economics, 92, 67-77.

Aksnes, D. W., Langfeldt, L., \& Wouters, P. (2019). Citations, citation indicators, and research quality: An overview of basic concepts and theories. Sage Open, 9(1), 1-17

Anderson, D. H. \& Fulton, D. C. (2008). Experience preferences as mediators of the wildlife related recreation participation: Place attachment relationship. Human Dimensions of Wildlife, 13(2), 73-88.

Beeco, J. A., Hallo, J. C., \& Brownlee, M. T. (2014). GPS visitor tracking and recreation suitability mapping: Tools for understanding and managing visitor use. Landscape and Urban Planning, 127, 136-145.

Beeco, J. A. \& Brown, G. (2013). Integrating space, spatial tools, and spatial analysis into the human dimensions of parks and outdoor recreation. Applied Geography, 38, 76-85.

Beery, T. \& Jönsson, K. I. (2017). Outdoor recreation and place attachment: Exploring the potential of outdoor recreation within a UNESCO Biosphere Reserve. Journal of Outdoor Recreation and Tourism, 17, 54-63.

Berlyne, D. E. (1973). Aesthetics and psychobiology. Journal of Aesthetics and Art Criticism, 31 (4), 553-553

Bitner, M. J. (1992). Servicescapes: the impact of physical surroundings on customers and employees. Journal of Marketing, 56 (2), 57-71.

Bricker, K. S. \& Kerstetter, D. L. (2000). Level of specialization and place attachment: An exploratory study of whitewater recreationists. Leisure sciences, 22(4), 233257.

Brouwer, R., Martin-Ortega, J. \& Berbel, J. (2010). Spatial preference heterogeneity: a choice experiment. Land Economics, 86(3), 552-568.

Brown, P. J., Dyer, A. \& Whaley, R. S. (1973). Recreation research-so what?. Journal of Leisure Research, 5(1), 16-24.

Bryan, H. (1977). Leisure value systems and recreational specialization: The case of trout fishermen. Journal of leisure Research, 9(3), 174-187.

Carls, E. G. (1974). The effects of people and man-induced conditions on preferences for outdoor recreation landscapes. Journal of Leisure Research, 6, 113-124.

Cheng, C. K. \& Kuo, H. Y. (2015). Bonding to a new place never visited: Exploring the relationship between landscape elements and place bonding. Tourism Management, 46, 546-560.

Chenoweth, R. E. \& Gobster, P. H. (1990). The nature and ecology of aesthetic experiences in the landscape. Landscape Journal, 9(1), 1-8.

Cheung, D. M. W. \& Tang, B. S. (2016). Recreation space or urban land reserve? Land-use zoning patterns and the transformation of open space in Hong Kong. Journal of Urban Planning and Development, 142(3).

Chung, J. Y., Kyle, G. T., Petrick, J. F., \& Absher, J. D. (2011). Fairness of prices, user fee policy and willingness to pay among visitors to a national forest. Tourism Management, 32(5), 1038-1046.

Defilippis, J. (1997). From a public re-creation to private recreation: The transformation of public space in South
Street Seaport. Journal of Urban Affairs, 19(4), 405-417.

De Groot, W. T. \& van den Born, R. J. (2003). Visions of nature and landscape type preferences: an exploration in The Netherlands. Landscape and urban planning, 63(3), 127-138.

Donovan R. \& Rossiter, J. (1982). Store atmosphere: an environmental psychology approach. Journal of Retailing, 58 (1), 34-57.

Fishwick, L. \& Vining, J. 1992. Toward a phenomenology of recreation place. Journal of Environmental Psychology, 12: 57-63.

Garrigos-Simon, F. J., Narangajavana-Kaosiri, Y., \& Narangajavana, Y. (2019). Quality in tourism literature: A bibliometric review. Sustainability, 11(14), 3859-3881.

Gieseking, J. J., Mangold, W., Katz, C., Low, S., \& Saegert, S. (2014). Place and Identity. In The people, place, and space reader. London: Routledge.

Gross, M. J. \& Brown, G. (2008). An empirical structural model of tourists and places: Progressing involvement and place attachment into tourism. Tourism management, 29(6), 1141-1151.

Hailu, G., Boxall, P. C., \& McFarlane, B. L. (2005). The influence of place attachment on recreation demand. Journal of Economic Psychology, 26(4), 581-598.

Hall, C. M. \& Page, S. J. (2014). The geography of tourism and recreation: Environment, place and space (4th Ed.). London: Routledge.

Hammitt, W. E., Backlund, E. A., \& Bixler, R. D. (2006). Place bonding for recreation places: Conceptual and empirical development. Leisure studies, 25(1), 17-41.

Hammitt, W. E., Kyle, G. T., \& Oh, C. O. (2009). Comparison of place bonding models in recreation resource management. Journal of Leisure Research, 41(1), 57-72.

Hansen, D. L., Shneiderman, B., Smith, M. A., \& Himelboim, I. (2011). Social network analysis: measuring, mapping, and modeling collections of connections. In Analyzing social media networks with NodeXL: insights from a connected world. Burlington: Elsevier Inc.

Hay, R. (1998). Sense of place in developmental context. Journal of Environmental Psychology, 18(1), 5-29.

Heintzman, P. (2009). Nature-based recreation and spirituality: A complex relationship. Leisure Sciences, 32(1), 72-89.

Hidalgo, M. C. \& Hernandez, B. (2001). Place attachment: Conceptual and empirical questions. Journal of Environmental Psychology, 21(3), 273-281.

Hwang, S. N., Lee, C., \& Chen, H. J. (2005). The relationship among tourists' involvement, place attachment and interpretation satisfaction in Taiwan's national parks. Tourism Management, 26(2), 143-156.

James, K. (2000). You can feel them looking at you: The experiences of adolescent girls at swimming pools. Journal of Leisure Research, 32(2), 262-280.

Jiang, Y., Ritchie, B. W., \& Benckendorff, P. (2019) Bibliometric visualisation: an application in tourism crisis and disaster management research. Current Issues in Tourism, 22(16), 1925-1957.

Johnson, C. Y. (1998). A consideration of collective memory in African American attachment to wildland recreation places. Human Ecology Review, 5 (1), 5-15.

Jorgensen, B. S. \& Stedman, R. C. (2001). Sense of place as 
an attitude: Lakeshore owners attitudes toward their properties. Journal of Environmental Psychology, 21(3), 233-248.

Kaltenborn, B. P. (1997). Nature of place attachment: A study among recreation homeowners in Southern Norway. Leisure Sciences, 19(3), 175-189.

Kaplan, R. \& Kaplan, S. (1989). The Experience of Nature: A Psychological Perspective. Cambridge: Cambridge University Press.

Kaplan, R., Kaplan, S., \& Ryan, R. (1998). With people in mind: Design and management of everyday nature. London: Island press.

Kienast, F., Degenhardt, B., Weilenmann, B., Wäger, Y., \& Buchecker, M. (2012). GIS-assisted mapping of landscape suitability for nearby recreation. Landscape and Urban Planning, 105(4), 385-399.

Kim, Y. G. \& Eves, A. (2012). Construction and validation of a scale to measure tourist motivation to consume local food. Tourism management, 33(6), 1458-1467.

Komossa, F., van der Zanden, E. H., Schulp, C. J., \& Verburg, P. H. (2018). Mapping landscape potential for outdoor recreation using different archetypical recreation user groups in the European Union. Ecological indicators, 85, 105-116.

Kyle, G. T., Absher, J. D., \& Graefe, A. R. (2003). The moderating role of place attachment on the relationship between attitudes toward fees and spending preferences, Leisure Sciences, 25(1), 33-50.

Kyle, G. ve Chick, G. (2007). The social construction of a sense of place. Leisure Sciences, 29(3), 209-225.

Kyle, G. T., Mowen, A. J., \& Tarrant, M. (2004). Linking place preferences with place meaning: An examination of the relationship between place motivation and place attachment. Journal of Environmental Psychology, 24(4), 439-454.

Kyle, G., Graefe, A., Manning, R., \& Bacon, J. (2004). Effect of activity involvement and place attachment on recreationists' perceptions of setting density. Journal of Leisure Research, 36(2), 209-231.

Kyle, G., Bricker, K., Graefe, A., \& Wickham, T. (2004). An examination of recreationists' relationships with activities and settings. Leisure Sciences, 26(2), 123-142.

Lewicka, M. (2008). Place attachment, place identity, and place memory: Restoring the forgotten city past. Journal of Environmental Psychology, 28(3), 209-231.

Line, N. \& Costen, W. (2011). Environmental attitudes, motivation, and attachment: Toward a model of nature-based tourism. International CHRIE Conference Proocedings.

Lee, R. G. (1972). The social definition of recreation places. In Social behavior, natural resources and the environment(Eds.:Burch,W. Jr., Cheek, N. Jr., \& Taylor, L. ), pp. 68-84. New York: Harper \& Row.

Loureiro, S. M. C. (2014). The role of the rural tourism experience economy in place attachment and behavioral intentions. International Journal of Hospitality Management, 40, 1-9.

Mehrabian, A. \& Russell, J. A. (1973). A measure of arousal seeking tendency. Environment and Behavior, 5(3), 315333.

Manzo, L. C. (2005). For better or worse: Exploring multiple dimensions of place meaning. Journal of Environmental Psychology, 25(1), 67-86.

Mccool, S. F. (1978). Recreation Use Limits: Issues for the Tourism Industry. Journal of Travel Research, 17(2), 2-7.

McDonough, M. H. (1981). The influence of place on recreation behavior: the case of Northeast Washington (Unpublished PhD Dissertation). University of Washington.

McIntyre, N. \& Pigram, J. J. (1992). Recreation specialization reexamined: The case of vehicle-based campers. Leisure Sciences, 14(1), 3-15.

Merigó, J. M., Mulet-Forteza, C., Valencia, C., \& Lew, A. A. (2019). Twenty years of Tourism Geographies: a bibliometric overview. Tourism Geographies, 21(5), 881-910.

Moncrief, L. W. (1970). The cultural basis for our environmental crisis: Judeo-Christian tradition is only one of many cultural factors contributing to the environmental crisis. Science, 170(3957), 508-512.

Moore, R. L. \& Graefe, A. R. (1994). Attachments to recreation settings: The case of rail-trail users. Leisure sciences, 16(1), 17-31.

Mulet-Forteza, C., Genovart-Balaguer, J., Mauleon-Mendez, E., \& Merigó, J. M. (2019). A bibliometric research in the tourism, leisure and hospitality fields. Journal of Business Research, 101, 819-827.

Murphy, R. E. (1963). Geography and outdoor recreation: An opportunity and an obligation. The Proffesional Geographer. 15(5). 33-34

Myron F. F. (1997) Pleasure, arousal, and dominance: Exploring affective determinants of recreation satisfaction. Leisure Sciences, 19(2), 83-96.

Okuyucu, A. \& Günay Aktaş, S. (2018). Turizmin mekânsal yapısını anlama. In Turistik alanlarda mekan tasarımı (Ed.: Günay Aktaş, S.), S:3-36. Eskişehir: Anadolu University Publish no: 3538

Pasadeos, Y., Phelps, J. \& Kim, B. H. (1998). Disciplinary impact of advertising scholars: Temporal comparisons of influential authors, works and research networks. Journal of Advertising, 27(4), 53-70.

Puustinen, J., Pouta, E., Neuvonen, M. ve Sievänen, T. (2009). Visits to national parks and the provision of natural and man-made recreation and tourism resources. Journal of Ecotourism, 8(1), 18-31.

Ramos-Rodríguez, A. R. \& Ruíz-Navarro, J. (2004). Changes in the intellectual structure of strategic management research: A bibliometric study of the Strategic Management Journal, 1980-2000. Strategic management journal, 25(10), 981-1004.

Prayag, G. \& Lee, C. (2018). Tourist motivation and place attachment: The mediating effects of service interactions with hotel employees. Journal of Travel \& Tourism Marketing, 36(1), 90-106.

Proshansky, H. M. (1978). The city and self-identity. Environment and Behavior, 10(2), 147-169.

Proshansky, H. M., Fabian, A. K., \& Kaminoff, R. (1983). Placeidentity: Physical world socialization of the self. Journal of Environmental Psychology, 3(1), 57-83

Raitz, K. \& Dakhil, M. (1988). Recreational choices and environmental preference. Annals of Tourism Research, 15(3), 357-370. 
Robinson, G. W. S. (1972). The recreation geography of South Asia. Geographical Review, 561-572.

Russell, J. A. \& Mehrabian, A. (1976). Environmental Variables in Consumer Research. Journal of Consumer Research, 3(1), 62-63.

Russell, J. A. \& Mehrabian, A. (1978). Approach-Avoidance and Affiliation as Functions of the Emotion-Eliciting Quality of an Environment. Environment and Behavior, 10(3), 355-387.

Schneider, I. E. (2009). Urban water recreation: experiences, place meanings, and future issues. In The water environment of cities (pp. 125-140). Boston: Springer.

Singh, S. N., Donavan, D. T., Mishra, S., \& Little, T. D. (2008). The latent structure of landscape perception: A mean and covariance structure modelling approach. Journal of Environmental Psychology, 28(4), 339-352.

Sime, J. D. (1995). Crowd psychology and engineering. Safety Science, 21(1), 1-14.

Smaldone, D., Harris, C. C., Sanyal, N., \& Lind, D. (2005). Place Attachment and Management of Critical Park Issues in Grand Teton National Park. Journal of Park \& Recreation Administration, 23(1), 90-114.

Small, H. (1973). Co-citation in the scientific literature: A new measure of the relationship between two documents. Journal of the American Society for Information Science, 24(4), 265-269.

Smith, J. W., Siderelis, C., \& Moore, R. L. (2010). The effects of place attachment, hypothetical site modifications and use levels on recreation behaviour. Journal of Leisure Research, 42(4), 621-640.

Soja, E. W. (1989). Postmodern geographies: The reassertion of space in critical social theory. New York: Verso.

Stedman, R. C. (2002). Toward a social psychology of place: Predicting behaviour from place-based cognitions, attitude, and identity. Environment and Behaviour, 34(5), 561-581.

Stedman, R. C. (2003). Is it just a social construction? The contribution of the physical environment to sense of place. Society \&Natural Resources, 16(8), 671-685.

Stedman, R. C. (2003a). Sense of place and forest science: toward a program of quantitative research. Forest Science, 49: 822-829.

Stokowski, P. A. (2002). Languages of place and discourses of power: Constructing new senses of place. Journal of leisure research, 34(4), 368-382.

Toth Jr, J. F. \& Brown, R. B. (1997). Racial and gender meanings of why people participate in recreational fishing. Leisure Sciences, 19(2), 129-146.

Vaske, J. J. \& Kobrin, K. C. (2001). Place attachment and environmentally responsible behaviour. The Journal of Environmental Education, 32(4), 16-21.

Wakefield, K.L. \& Blodgett, J.G. (1996). The effect of the servicescape on customers' behavioural intentions in leisure service settings. Journal of Services Marketing, $10(6), 45-61$.

Warzecha, C. A. \& Lime, D. W. (2001). Place Attachment in Canyonlands National Park: Visitors' Assessment of Setting Attributes on the Colorado and Green Rivers. Journal of Park \& Recreation Administration, 19(1), 59-78.

Weber, D. ve Anderson, D. (2010). Contact with nature: Recreation experience preferences in Australian parks.
Annals of Leisure Research, 13(1-2), 46-69.

Weyland, F. \& Laterra, P. (2014). Recreation potential assessment at large spatial scales: A method based on the ecosystem services approach and landscape metrics. Ecological Indicators, 39, 34-43.

Williams, D. R., Patterson, M. E., Roggenbuck, J. W., \& Watson, A. E. (1992). Beyond the commodity metaphor: Examining emotional and symbolic attachment to place. Leisure Sciences, 14(1), 29-46.

Williams, D. R. \& Stewart, S. I. (1998). Sense of place: An elusive concept that is finding a home in ecosystem management. Journal of Forestry, 96(5), 18-23.

Williams, D. R. \& Vaske, J. J. (2003). The measurement of place attachment: Validity and generalizability of a psychometric approach. Forest Science, 49(6), 830-840.

Wolfe, R. I. (1964). Perspective on outdoor recreation: a bibliographical survey. Geographical Review, 54(2), 203-238.

Tuan, Y. F. (1980). Rootedness versus the sense of place. Landscape, 24: 3-8.

Tuan, Y.F. (1998). Escapism. Baltimore: Johns Hopkins University Press.

Turley, L.W. \& Milliman, R.E. (2000). Atmospheric effects on shopping behaviour: a review of the experimental evidence. Journal of business research, 49 (2), 193-211.

Young, M. (1999). The relationship between tourist motivations and the interpretation of place meanings. Tourism Geographies, 1(4), 387-405.

Zhang, H., Chen, B., Sun, Z. \& Bao, Z. (2013). Landscape perception and recreation need in urban green space in Fuyang, Hangzhou, China. Urban Forestry \& Urban Greening, 12(1), 44-52.

Zube, E. H. (1984). Themes in Landscape Assessment Theory. Landscape Journal. 3(2): 104-110.

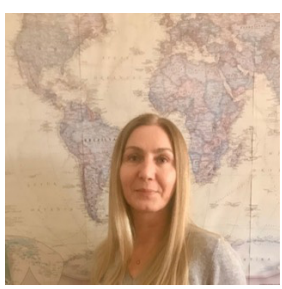

Deniz Karagöz is an associate professor in the Faculty of Tourism at the Anadolu University. Her research interests include tourist behavior, travel experience, event marketing and destination marketing.

ORCID: 0000-0003-2868-8567

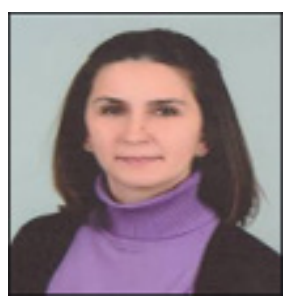

Selin Kama is a research assistant in the Faculty of Tourism at Bitlis Eren University. Her research interests include tourist behavior, recreation, planning and sustainability.

ORCID: 0000-0002-2707-091X 